\title{
Bio-efficacy of new molecules against sucking pests in summer cowpea
}

\author{
T. ANANDMURTHY ${ }^{1}$, G. M. PARMAR ${ }^{2 *}$ AND G. ARVINDARAJAN ${ }^{1}$ \\ ${ }^{1}$ Department of Entomology, Junagadh Agriculture University, JUNAGADH (GUJARAT) INDIA \\ ${ }^{2}$ Millet Research Station (J.A.U.), JAMNAGAR (GUJARAT) INDIA
}

\section{ARITCLE INFO}

Received : 20.07 .2017

Revised : 03.08 .2017

Accepted : 17.08 .2017

\section{KEY WORDS :}

Cowpea, Bioefficacy, Sucking pests, Dinotefuran, Flonicamid
*Corresponding author:

\begin{abstract}
Investigations was conducted to evaluate bio-efficacy of some new molecules of insecticides against major sucking pests of summer cowpea at Instructional Farm, College of Agriculture, Junagadh Agricultural University, Junagadh during summer 2016 with ten treatments and three replications. Among the tested insecticides, dinotefuran 0.006 per cent, acetamiprid 0.004 per cent and dimethoate 0.03 per cent were found most effective against jassids. The treatments of acetamiprid 0.004 per cent, dimethoate 0.03 per cent and spiromesifen 0.08 per cent were found most effective in reducing the whitefly population. The application of dinotefuran 0.006 per cent acetamiprid 0.004 per cent and dimethoate 0.03 per cent proved effective in recording minimum aphid population. The highest grain yield of cowpea $853 \mathrm{~kg} / \mathrm{ha}$ was recorded from the treatment of dinetofuran 0.006 per cent which was statistically at par with acetamiprid 0.004 per cent $(816 \mathrm{~kg} / \mathrm{ha})$, spiromesifen 0.08 per cent $(795 \mathrm{~kg} / \mathrm{ha})$, dimethoate 0.03 per cent $(790 \mathrm{~kg} / \mathrm{ha})$ and flonicamid 0.02 per cent $(752 \mathrm{~kg} / \mathrm{ha})$. On the basis of economics, acetamiprid 0.004 per cent $(1: 21.8)$ proved to be most economically viable treatment followed by dimethoate 0.03 per cent $(1: 21.2)$, spiromesifen 0.08 per cent (1:9.8), dinetofuran 0.006 per cent (1:9.4), chlorfenapyr 0.0075 per cent (1:5.8), clothianidin 0.003 per cent (1:5.5) and flonicamid 0.02 per cent (1:4.8).
\end{abstract}

How to view point the article : Anandmurthy, T., Parmar, G.M. and Arvindarajan G. (2017). Bio-efficacy of new molecules against sucking pests in summer cowpea. Internat. J. Plant Protec., 10(2) : 236-240, DOI : 10.15740/HAS/IJPP/10.2/236-240. 